This item was submitted to Loughborough's Research Repository by the author.

Items in Figshare are protected by copyright, with all rights reserved, unless otherwise indicated.

\title{
Towards improved labour standards for construction of minor works in low
} income countries

PLEASE CITE THE PUBLISHED VERSION

PUBLISHER

(c) Emerald

LICENCE

CC BY-NC-ND 4.0

REPOSITORY RECORD

Cotton, Andrew P., M. Sohail, and Rebecca E. Scott. 2019. "Towards Improved Labour Standards for Construction of Minor Works in Low Income Countries". figshare. https://hdl.handle.net/2134/3864. 
This item was submitted to Loughborough's Institutional Repository (https://dspace.lboro.ac.uk/) by the author and is made available under the following Creative Commons Licence conditions.

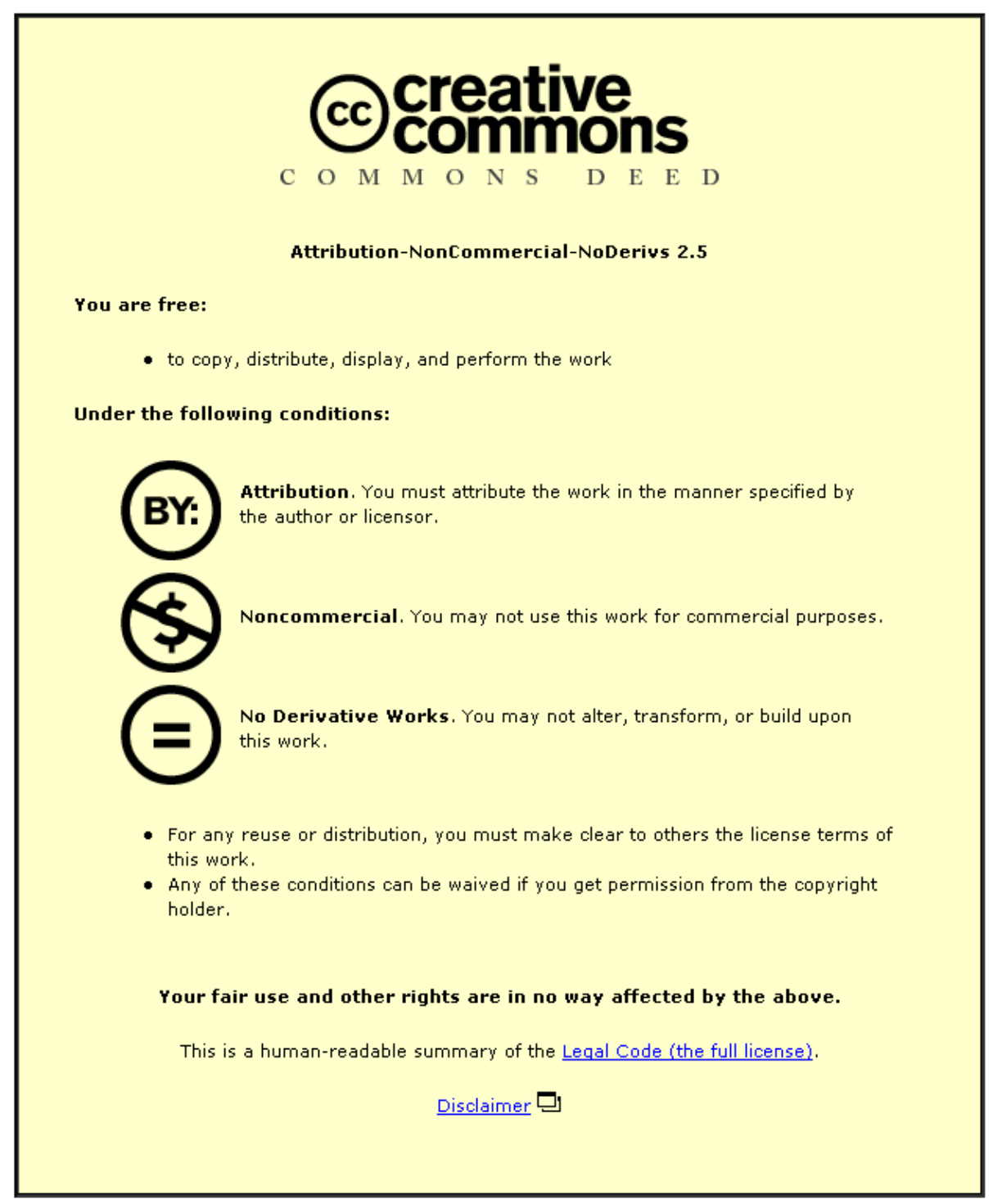

For the full text of this licence, please go to: http://creativecommons.org/licenses/by-nc-nd/2.5/ 
TOWARDS IMPROVED LABOUR STANDARDS FOR CONSTRUCTION OF MINOR WORKS IN LOW INCOME COUNTRIES

A.P. Cotton, M. Sohail, R.E. Scott

Word count: 6,347

Paper Type: Research paper 
A.P. Cotton

Senior Programme Manager, WEDC, Department of Civil and Building Engineering, Loughborough University, UK

M. Sohail (corresponding author)

Senior Research Manager, WEDC, Department of Civil and Building Engineering, Loughborough University, UK

E-MAIL: m.sohail@lboro.ac.uk

R.E. Scott

Assistant Programme Manager, WEDC, Department of Civil and Building Engineering, Loughborough University, UK 


\section{Structured Abstract}

\section{Purpose of the paper:}

The construction industry is one of the largest employment providers in the developing world. It is also one of the least safe industries, with a high frequency of accidents resulting in financial losses, injuries, disabilities and deaths. Decent working conditions and resulting improved worker satisfaction are key to sustainable productivity in the industry. International standards safeguarding construction workers are abundant and ratified by most low-income countries. Are these standards adequately reflected in contracts for construction works? If not, how can contract clauses be improved and operationalised?

\section{Design/methodology/approach:}

Based on research undertaken in Ghana, India and Zambia from 2000 to 2003, this paper explores the aforementioned questions. The paper comprises of analysis of contract clauses from the International Federation of Consulting Engineers (FIDIC) and developing country contracts, along with cases study findings.

\section{Findings:}

This paper finds that more legislation is not the urgent issue; incorporating existing legislation into construction contracts and making clauses operational is a priority. This paper identifies practical and cost-effective procedures for bringing stakeholders together to implement and monitor labour standards, with the aim of contributing to the overall goal of providing "decent work" for all workers in the construction industry.

\section{Original/value of the paper:}

This paper explores issues around implementing labour standards in construction of minor infrastructure works in low income countries and concludes with suggestions on how best to operationalise contract clauses through a process approach. 
Key words: labour standards, construction, contracts, developing countries 


\section{Introduction}

This paper aims to explore the issues around implementing labour standards in construction of minor infrastructure works in low income countries. Case studies from Ghana, India and Zambia are used to illustrate the importance of developing a process of implementation as a necessary complement to having the appropriate contractual framework in place.

The scope of infrastructure considered in this paper primarily affects the provision of water, sanitation, drainage, transport and other such services that are typically provided through minor works. Currently over 1.2 billion people are without a safe drinking water supply and 2.6 billion people (almost a third of the world's population) are without access to basic sanitation services (WHO/UNICEF, 2004). The daily lives of billions of people in the developing world are influenced by improvements to address the backlog in the provision of such services, involving substantial investment in the construction sector, predominately through minor infrastructure works.

\section{The Context}

The construction industry - and notably that part involving minor infrastructure works - is a major employment provider in the developing world. However, it also provides very hazardous work for what is typically a casually employed and low or unskilled workforce.

- In Uganda, between 1996 and 1998 there were 146 recorded accidents in the construction industry - 30 per cent of all industrial accidents recorded in that period (Lubega et al, 2000).

- In comparison, the construction industry accounted for 31 per cent of all work-related fatal injuries in the UK during the period 2002/2003 (HSC, undated).

More generally, almost six times as many fatalities and twice as many injuries per hour worked occur in the construction industry compared with the manufacturing industry (Helander, 1991).

In the case of minor construction works in low-income countries, the adoption of health and safety standards is an essential element of protecting workers. While workers may be more concerned with standards about wages being paid in full and on time, addressing health and safety issues often 
provides a useful entry point for developing understanding and awareness, procedures and capacity for Employers and Contractors to address labour standards that are further prioritised by all stakeholders.

International labour standards are abundant and most developing countries have signed conventions such as those drafted by the International Labour Organisation (ILO, 1987, 1990 and 1991). However, the important issue here is whether such standards and convention requirements are applied in practice.

\section{Labour standards}

The International Labour Organisation (ILO) is the key organisation in setting standards and creating consensus among nations to sign conventions. However, results remain inconclusive in terms of those conventions achieving tangible changes in construction practice in many developing countries.

The ILO’s four core labour standards cover:

1. Freedom of Association and the right to collective bargaining

2. Elimination of forced or compulsory labour

3. Effective abolition of child labour

4. Elimination of discrimination in respect of employment and occupation

These standards are stated in the Declaration on Fundamental Principles and Rights at Work, adopted by the ILO in 1998 (ILO, 1998). The Declaration applies automatically to all countries that have accepted the ILO Constitution, and this includes the case study countries.

A worker's well-being depends on the provision of decent working conditions. These can be brought about through the application of both the core standards above and broader labour standards based on international conventions of the ILO, along with provisions within regional and national law.

The Department for International Development (DFID) identifies five broader labour standards:

5. Consideration for health and safety

6. Payment of wages in full and on time

7. Limitations on working hours and overtime pay

8. Prevention of repeated casualisation (replacement of permanent employees by casual workers) 
9. Application of social security regimes

(DFID, 2004)

Taken together, these nine labour standards affect people’s basic rights and freedoms, enhance dignity and promote well-being, and so have an effect on the social, political and financial capital of construction workers. In the context of low-income countries the effects can be identified, for example, in relation to four labour standards:

- Freedom of association and the right to collective bargaining is especially relevant in the informal labour market, which makes up the vast majority of waged labour in developing countries, because otherwise such workers have no voice.

- Adequate health and safety measures can protect labourers from wages lost through injury.

- Limited casualisation helps ensure the payment of wages and legal benefits.

- An end to discrimination ensures that skills and capabilities are not wasted.

Together, such improvements support the livelihoods of the poor, reducing their vulnerability to various "shocks" such as unexpected illness, injury or redundancy.

In the broader context, improved working conditions and worker health result in a lower turnover of staff, promoting greater cooperation and motivation within the workforce. Hence, if done gradually and correctly, application of labour standards also provides benefits to the employer by contributing to productivity (Ladbury, 2001). All this can, in turn, foster the social justice and political stability necessary to promote economic growth and greater private and public investment in the sector.

The Millennium Development Goals (MDGs) seek to combat extreme poverty and address human development in areas of hunger, disease, illiteracy, environmental degradation and discrimination against women (UN, 2002). Most of these targets can be met only with a significant contribution from the construction industry in terms of provision of infrastructure for services and improvements in the quantity and quality of work available for the poor in developing countries. International development agencies generally recognise the employment contribution of the industry, but their interest seldom 
extends beyond that. Meanwhile, the assumption that "any job is better than no job" has been the working hypothesis of many policymakers. As the connection between the application of social considerations with the productivity and sustainability of the construction industry become more widely understood and acknowledged, it is hoped these attitudes will change.

Contract clauses are a significant part of a larger framework within which construction and allied activities are organised. The following methodology was adopted to answer whether or not social considerations such as labour standards are reflected at all and/or adequately in contract clauses. Where this is not the case, how can contract clauses be improved and put into operation?

\section{Research methodology}

In the three case study countries - Ghana, India and Zambia - the introduction of labour standards into the contract was based on a process of broad stakeholder consultation.

The first stage of the research involved the collection of background information through a review of literature and contract conditions. This resulted in a decision to focus on labour standards as a representative issue for social considerations. The contract clauses reviewed came from the construction industries in the case study countries. These clauses were then compared against interim contract clauses proposed for use in the Department for International Development's (DFID) infrastructure programme in a large number of developing countries ${ }^{1}$. The key stage of research was based around fieldwork in Ghana, India and Zambia. This involved holding a series of semi-structured interviews, focus group discussions and workshops conducted with people with experience of international construction and international development: contractors, engineers, social development experts, representatives of trade unions, representative of non-government organisations (NGOs), politicians, workers and representatives of financial institutions. Data was collected from these

\footnotetext{
${ }^{1}$ While interim clauses were in place at the time of the study, they have not been formally adopted by DFID.
} 
workshops/group meetings and discussions in each case country. In addition, a total of approximately 100 key informant interviews were carried out.

In Ghana, the research process developed a consultation model later adapted to suit the India and Zambia cases. The three key phases involved:

First phase: Developing the evidence base through an extensive review of all relevant national laws and by-laws, existing FIDIC conditions of contract and national framework agreements. This was followed by extensive base-line studies on 40 construction sites, identifying actual practice against legal requirements. This involved observation, interviews, focus-group discussions and discussions at site meetings, engaging an extensive range of site staff and workers.

Second phase: Stakeholder consultation was enabled through a series of workshops held over a 3 year period. The first 2-day stakeholder workshop was hosted by a government department (the Employer) and facilitated by a qualified engineer from a Ghana-based NGO. This established agreement from a broad range of stakeholders to address labour standards in a rural roads bridge construction project. Subsequent six-monthly workshops focused on addressing the implementation of prioritised labour standards; giving time for feedback from the application of each standard, an opportunity to identify underlying causes of the difficulties encountered and proposing solutions to make implementation "workable”.

Third phase: This involved scaling-up and scaling-out the process and findings. A broader range of stakeholders were brought in to the labour standards debate, to encourage the adaptation of contracting and monitoring procedures accordingly. The issue was to institutionalise labour standards into contract clauses funded by other donors, or direct government-funded programmes. The research study provided example contract clauses, cost estimates, training and briefing materials to support this.

In Kerala State, India, the comprehensive decentralised nature of local government means that the local elected councils (Panchayats) are typically the 'employers', with local contractors and unskilled community members the workers. The institutional context in India, a system of community- 
contracting, changed the composition of the stakeholder group, but the research methodology mirrored the Ghana case quite closely.

Trained staff of a Kerala-based development organisation (the Socio-Economic Unit Foundation, SEUF) reviewed contracts relating to 18 minor works being conducted across six districts in Kerala State. Site visits were carried out at 5 of the construction sites, enabling direct observation of the implementation of labour standards. Interviews were also held with workers associated with all projects, enabling over 200 people to interact with the research.

In Zambia the 'employers' in the DFID-financed water and sanitation upgrading scheme were communities themselves, being asked to provide their labour voluntarily as 'contribution' to the projects. This necessitated adaptation of the Ghana model, as there was an evident lack of a statutory regulatory framework that could be applied to work supplied free of charge (except prohibition of forced labour). Emphasis of the consultation process consequently shifted, both in terms of the priority labour standards (gender equality, regulation of working hours and 'lack' of pay) and the stakeholder consultation group (with greater involvement from communities).

Full stakeholder workshops were conducted in all 3 case study countries, at which findings from the literature and contract review, interviews, focus-group discussions and observations were presented and amended in the light of contributions made during the workshops themselves.

\section{Contract clauses and labour standards}

Table I provides examples of contract clauses that are relevant to labour standards in construction. Although the clauses described below were mainly used, the authors also carried out triangulation with other clauses in various countries such as Tanzania, Pakistan and Sri Lanka.

The Conditions of Contract used for analysis were: Part 1 and 2 of the 4th Edition of FIDIC Conditions of Contract (FIDIC, 1987) (particular attention was paid here as this, and its derivatives, are used 
widely in international procurement); the Feeder Roads Bridges Project, Department of Feeder Roads, Ministry of Roads and Transport, Ghana; the Public Works Department, States of Kerala and Orissa, India; and the DFID interim clauses (unpublished). 
Table I: Summary of relevant contract clauses

Note: Abbreviation $\mathbf{C l}$ refers to the Clause number as recorded on the authors' database.

\begin{tabular}{|c|c|c|}
\hline Labour standard & Relevant FIDIC clauses $^{2}$ & Relevant clauses from other documents ${ }^{3}$ \\
\hline Freedom of association & & $\begin{array}{l}\text { Ghana } \mathrm{Cl} 34.10 \text { Contractor must recognise workers right to trade } \\
\text { union membership. }\end{array}$ \\
\hline Equality of treatment & & $\begin{array}{l}D F I D C l A \text { states that men and women should receive equal rates of } \\
\text { pay. DFID } C l \mathrm{~K} \text { provides for records to allow monitoring. }\end{array}$ \\
\hline $\begin{array}{l}\text { Wages } \\
\text { 1. Minimum wages } \\
\text { 2. Timeliness of } \\
\text { payment }\end{array}$ & - FIDIC Part II Cl 34(i) covers minimum wage rates. & $\begin{array}{l}\text { 1. Ghana } \mathrm{Cl} 34.2 \text { covers wage rates. } \mathrm{DFID} \mathrm{Cl} \mathrm{A} \text { states in addition } \\
\text { that payment should be in cash. Ghana } \mathrm{Cl} 34.5 \text { display notices } \\
\text { informing workers of their entitlements, } \mathrm{Cl} 34.18 \text { makes it a } \\
\text { requirement that the Contractor has paid wage rates of at least the } \\
\text { minimum for three months prior to bidding. India } \mathrm{Cl} \mathrm{P} \text { makes } \\
\text { "fair wage" a requirement. } \mathrm{Cl} M \text { requires the Contractor to pay not } \\
\text { less than that paid for similar work in the neighbourhood. }\end{array}$ \\
\hline 3. Payment records & & $\begin{array}{l}\text { 2. Ghana } \mathrm{Cl} 34.3 \text { states that employees should be paid promptly and } \\
\text { regularly. If the Contractor fails to comply with the above, } \mathrm{Cl} \\
\text { 34.19, India } \mathrm{Cl} R \text { covers payment by the Engineer out of monies } \\
\text { due to the Contractor. }\end{array}$ \\
\hline & & $\begin{array}{l}\text { 3. Ghana } \mathrm{Cl} 34.6 \text { covers payment records; } \mathrm{DFID} \mathrm{Cl} \mathrm{K} \text { is similar but } \\
\text { provides for more detailed records to include information on } \\
\text { gender and casual/permanent labour. }\end{array}$ \\
\hline $\begin{array}{l}\text { Working hours } \\
\text { 1. Conditions of work }\end{array}$ & $\begin{array}{l}\text { 1. FIDIC Part I Cl } 45.1 \text { states that working at night or on } \\
\text { recognised days of rest is not allowed. (This is primarily for }\end{array}$ & 1. DFID Cl K provides for detailed records to include information on \\
\hline
\end{tabular}

${ }^{2}$ Where no FIDIC Clause is identified in this column, this is because there is no equivalent information relevant to the specific Labour Standard under consideration.
${ }^{3}$ Full details of the local contracts are provided in Ladbury, Cotton and Jennings (2003). 


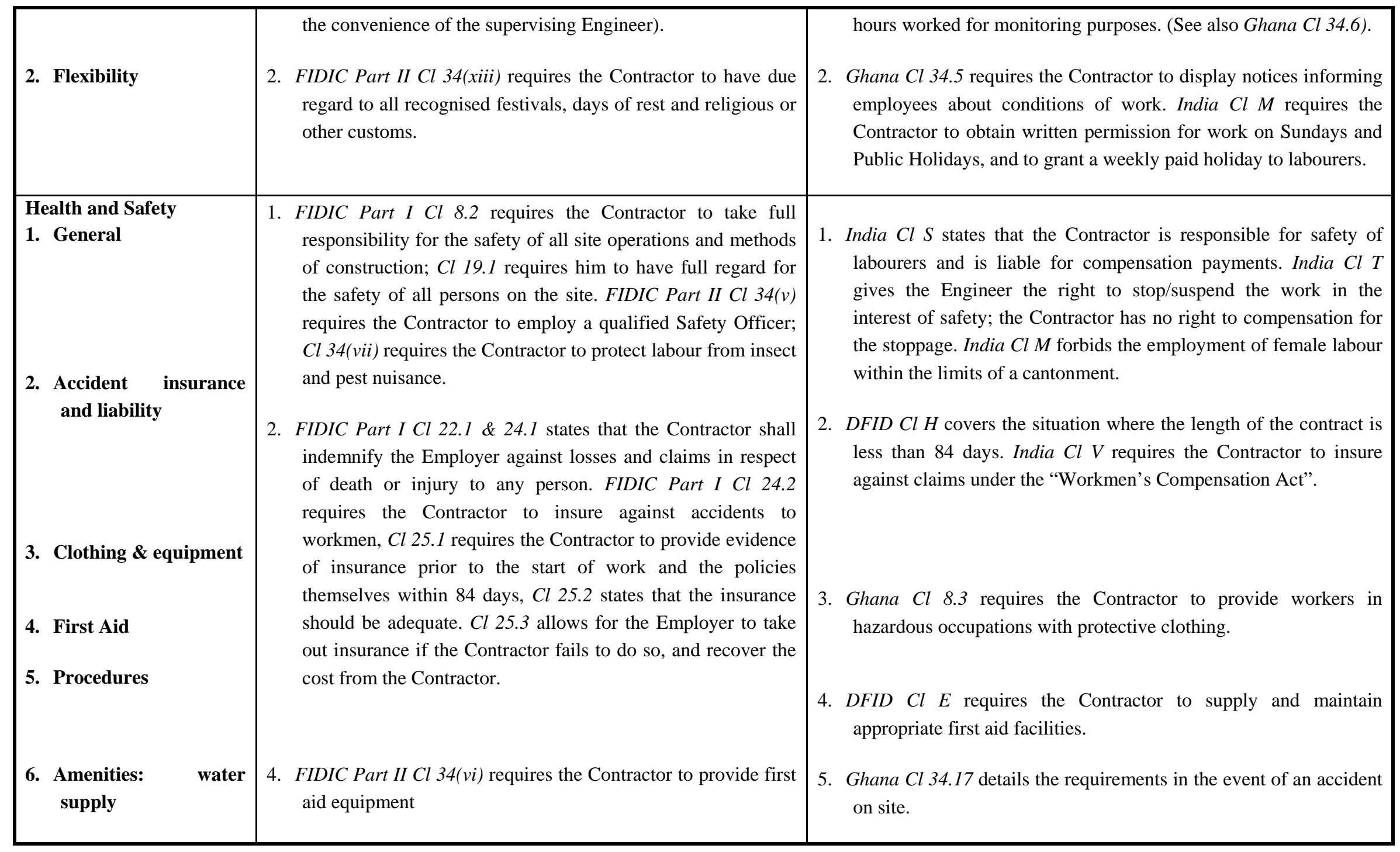




\begin{tabular}{|c|c|c|}
\hline 7. Amenities: sanitation & $\begin{array}{l}\text { 5. FIDIC Part II Cl 34(viii) requires the Contractor to comply } \\
\text { with the requirements of the local authority in the event of an } \\
\text { epidemic. FIDIC Part II } \mathrm{Cl} 35 \text { covers accident records and } \\
\text { reports. } \\
\text { 6. FIDIC Part II Cl 34(xa) requires the Contractor to provide an } \\
\text { adequate supply of drinking water "so far as is reasonably } \\
\text { practicable, having regard to local conditions". } \\
\text { 7. FIDIC Part II Cl 34(iv) requires the Contractor to provide } \\
\text { sanitation at the accommodation he provides for his labour. } \\
\text { 8. FIDIC Part II Cl 34(x) requires the Contractor to provide } \\
\text { suitable food at reasonable prices to his workforce. } \\
\text { 9. FIDIC Part II } \mathrm{Cl} 34(\text { iv) requires the Contractor to provide, } \\
\text { maintain and furnish accommodation for the workers. }\end{array}$ & $\begin{array}{l}\text { 6. Ghana } \mathrm{Cl} 34.8 \text { strengthens the FIDIC requirement for the } \\
\text { Contractor to supply safe drinking water. India } \mathrm{Cl} \mathrm{N} \text { requires the } \\
\text { Contractor to provide drinking water at his own cost for his labour } \\
\text { camp. } \\
\text { 7. Ghana } C l 34.9 \text { requires the Contractor to provide a specific type of } \\
\text { latrine; } D F I D C l D \text { is similar, only does not specify the type of } \\
\text { latrine and requires separate arrangements for men and women. } \\
\text { India } C L ~ N \text { requires the Contractor to provide "sanitary } \\
\text { arrangements" at his own cost for his labour camp. } \\
\text { 8. DFID } C l F \text { adds the requirement to provide clean shelters for the } \\
\text { consumption of food. } \\
\text { 9. Ghana } C l \text { 34.7 requires the Contractor to arrange for the } \\
\text { accommodation of his staff and labour. }\end{array}$ \\
\hline $\begin{array}{l}\text { Casualisation } \\
\text { - Conditions of work }\end{array}$ & & $\begin{array}{l}\text { - DFID Cl K provides for detailed records to include information on } \\
\text { casual/permanent labour. }\end{array}$ \\
\hline $\begin{array}{l}\text { Social security regimes } \\
\text { - Welfare }\end{array}$ & & $\begin{array}{l}\text { - India } \mathrm{Cl} \mathrm{W} \text { states that } 1 \% \text { of cost of construction to be remitted to } \\
\text { the construction workers welfare fund. }\end{array}$ \\
\hline Employment of children & & $\begin{array}{l}\text { DFID Cl G forbids the employment of children. India } \mathrm{Cl} \mathrm{M} \text { forbids the } \\
\text { employment of anyone below the age of } 12 \text {. }\end{array}$ \\
\hline Forced labour & & (Nothing found) \\
\hline HIV/Aids & & $\begin{array}{l}\text { Separate proposed HIV Clause requires Contractor to provide HIV } \\
\text { Awareness Programme (See Section 3). }\end{array}$ \\
\hline $\begin{array}{l}\text { Other } \\
\text { 1. Engagement of labour }\end{array}$ & $\begin{array}{l}\text { 1. FIDIC Part I Cl } 34.1 \text { makes the Contractor responsible for the } \\
\text { engagement, payment, housing, feeding and transport of all }\end{array}$ & $\begin{array}{l}\text { 1. Ghana } \mathrm{Cl} 34.1 \text { encourages the Contractor to employ labour from } \\
\text { within Ghana. India } \mathrm{Cl} M \text { requires "tribes of the locality" to be }\end{array}$ \\
\hline
\end{tabular}




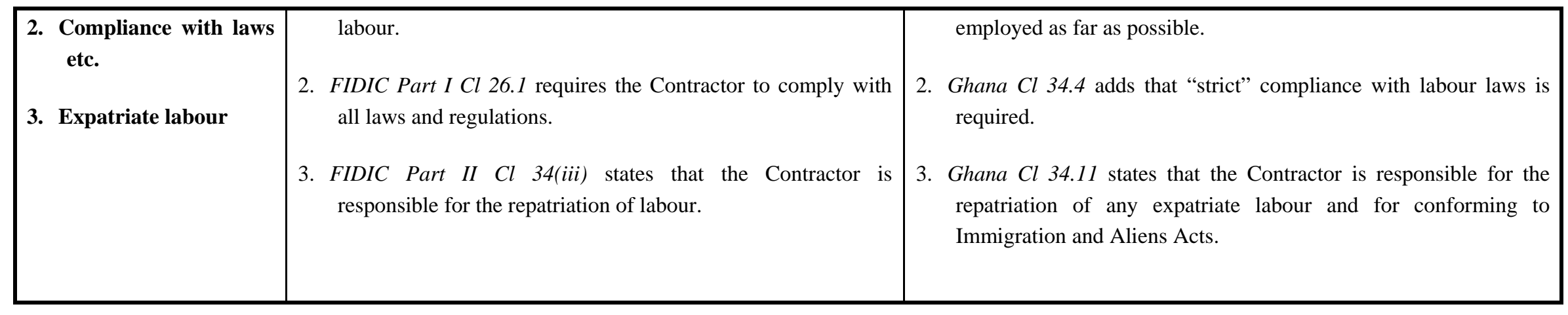




\section{Lessons from country case studies}

Fieldwork was undertaken to consider the contribution of applying labour standards to improved working conditions in both formal and informal contract arrangements. Observation of site practice was complimented by interviews held with site staff (labourers, supervisors, Engineers) and the inclusion of labour standards issues in regular site meetings.

The following sections provide a summary of lessons learned from each case study, giving the most pertinent aspects relating to the implementation and monitoring of labour standards in each country. Initial findings and recommendations from the research were verified with key stakeholders during workshops.

For further details see Ladbury, Cotton and Jennings (2003).

\section{Ghana}

The case study in Ghana was based around small-scale, formal contracting in a DFID-funded rural bridges scheme. A priority for the Department of Feeder Roads was to cost labour standards into the tender documents, through the inclusion of social clauses. The call for bids specified the application of labour standards but contractors, unaware of the implications, did not cost in the requirements (provision of safety equipment, water, sanitation facilities etc.). A "partnering” process enabled the client to work with the contractors to develop understanding of these requirements. Provision for implementing labour standards could then be reflected as prime cost items in the Bill of Quantities.

A key lesson here was the importance of developing a process for building labour standards into contract clauses.

- Contractors need to understand the implications of labour standards; and

- Contract documents should provide sufficient detail of what is required, to enable Contractors to prepare comprehensive and comparative bids.

All stakeholders agreed the experience gained in this case should be used to work for the adoption of labour standards as normal practice within the construction sector. The next step is to institutionalise labour standards. In pursuit of that aim, the following areas must be addressed:

- A consultative approach, with all relevant stakeholders represented, is needed if enforcement of standards is to be workable. 
- Costs associated with labour standards should be incorporated into the Bill of Quantities wherever possible.

- Monitoring the application of labour standards is crucial. For example, labourers may appear to work voluntarily 12-hour shifts, 7 days a week, but may do so to avoid penalties.

- While labour standards may appear to be adhered to on construction sites, they may be breached in the wider supply chain.

- Training and raising awareness should be part of capacity development of local contractors.

The provision of decent working conditions, supported through adoption of labour standards in infrastructure development, is part of the ongoing tripartite debate (involving governments, employers' and workers’ organisations) as Ghana develops and implements its Poverty Reduction Strategy.

\section{Kerala, India}

Research in Kerala focused on government-funded infrastructure development (with no donor involvement), in the context of a very comprehensive decentralisation programme. Extensive decentralisation in the State of Kerala has resulted in a wide range of construction projects, including road upgrading and water supply schemes, being implemented through local self-government elected councils (panchayats). Many of these schemes operate within a system of community-contracting.

The study found that the informal, unskilled and unpaid labour force working on these state projects is not covered by state social security legislation and is therefore not protected.

The study focussed on health and safety measures and equalisation of wages between men and women, standards that are largely ignored. It found that as community-contracting groups are generally not registered, an appropriate legal and regulatory framework is required.

- Where workers' rights and social clauses are not incorporated in legislation, labourers - often amongst the poorest people - bear the social and financial costs. Workers must therefore be made aware of their rights.

- Community leaders must be aware of their obligations under community-contracting schemes and develop mechanisms to protect their workers and themselves.

- Strong social relationships are a significant safeguard for workers. However, this can work against labourers where, for example, pressure is put on an injured worker not to claim for costs against a community leader. 


\section{Zambia}

In Zambia, community members contributed voluntary labour in a number of international NGOfunded water supply projects. This approach is commonly adopted as a means of promoting community "ownership” and ensuring an element of cost-sharing.

Strong social relationships existed between those managing the community-based construction and the labourers. This can help promote compliance with labour standards, but can also lead to coercion and a disparity in who bears the burden when standards are not met. Poorer households, who are more likely to provide labour contributions, are unlikely to challenge community leaders if wage payments are delayed, for instance.

- Short-term unpaid work may be acceptable to communities, if close consultation precedes any agreements. However, long-term unpaid work risks undermining livelihoods.

- The objectives of a voluntary unpaid approach should be clear and adopted only if understood and agreed to by all stakeholders. Such an approach should ensure:

o equality of treatment;

0 protection of health and safety; and

o a ban on child labour.

- All labour standards, except those relating to wages and casualisation, apply to unpaid work.

- Conditions of unpaid work must be clear about:

o its scale and frequency;

o the complexity and safety of the tasks involved; and

o skill requirements.

\section{Making clauses operational}

Table II takes each labour standard and provides a checklist of points to help professionals get started with developing the specification in relation to labour standards. Many of the points raise yet more issues - for example, under health and safety, what protective clothing should be provided? However, such decisions will depend upon the location and nature of the work. 
Table II: Getting started

\begin{tabular}{|c|c|}
\hline $\begin{array}{l}\text { Labour } \\
\text { standards }\end{array}$ & Checklist for "getting started" \\
\hline Health and safety & $\begin{array}{l}\text { Clothing and equipment: } \\
\text { What is to be provided? } \\
\text { Who is responsible for procurement and payment? } \\
\text { Who is responsible for storage and issue? } \\
\text { First Aid: } \\
\text { What are the contents of equipment/kits to be provided? } \\
\text { What is the number and location of equipment/kits? } \\
\text { Who is responsible for checking, replenishing and updating contents? } \\
\text { Who are the designated persons trained in first aid? } \\
\text { Have local clinics or health centres been notified about the works? } \\
\text { Procedures: } \\
\text { If treatment is required, who treats and who pays? } \\
\text { Has a safety officer been appointed? } \\
\text { Who is responsible for maintaining records of accidents? } \\
\text { Amenities: water supply } \\
\text { Level of service, e.g. per capita quantities, location of supply points, source of water, measures } \\
\text { to protect water quality and so on } \\
\text { Washing and bathing facilities/designated areas } \\
\text { Amenities: sanitation } \\
\text { Number of latrine cubicles, separate male/female facilities } \\
\text { Design for latrine superstructure and disposal system (e.g. pit, septic tank) } \\
\text { Amenities: food } \\
\text { Provision of canteen if appropriate } \\
\text { Amenities: shelter } \\
\text { Provision of shelter for non-local workers if appropriate }\end{array}$ \\
\hline Social security & $\begin{array}{l}\text { Welfare: } \\
\text { Registration of workers with the social security agency } \\
\text { Employer's contributions to any scheme } \\
\text { Employee's contributions to any scheme } \\
\text { Maintaining records of employees registration } \\
\text { Accident insurance cover: } \\
\text { Employer's protection against serious accidents involving an employee's death or physical } \\
\text { disability } \\
\text { Registration with state or national insurance cover schemes } \\
\text { Details of cover provided, e.g. for both permanent and casual workers } \\
\text { Maintaining records of insurance cover }\end{array}$ \\
\hline $\begin{array}{l}\text { Sufficient and } \\
\text { prompt payment of } \\
\text { wages }\end{array}$ & $\begin{array}{l}\text { Minimum wages: } \\
\text { Complying with legal minimum wages locally and/or nationally } \\
\text { Pay records } \\
\text { Maintaining records of payment to employees (normal and overtime) } \\
\text { Rates of pay for normal time and overtime } \\
\text { Dates/times at which wages paid }\end{array}$ \\
\hline $\begin{array}{l}\text { Regulated working } \\
\text { hours }\end{array}$ & $\begin{array}{l}\text { Conditions of work: } \\
\text { Number of normal working hours per day or per week }\end{array}$ \\
\hline
\end{tabular}


Casualisation and equality of treatment of casuals

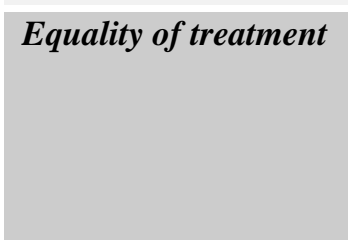

\section{Freedom of} association

\section{No forced labour}

Restricted employment of children
Timing of normal working hours

Overtime working, whether voluntary or obligatory

Requirements to work "unsocial times” or shifts

Flexibility:

Altering working hours to suit working mothers

Working hours taking account of seasonal responsibilities

Conditions of work:

Definitions of "permanent” or "casual” workers

Restrictions or otherwise on the use of casual workers

Differences in pay and/or conditions for casual/permanent workers

\section{Gender disparity:}

Is there any disparity in wages between men and women?

Quotas/guidelines for numbers of men/women employed

Use of pay records as a means of monitoring

\section{Trade unions:}

Recruitment and organisation of labour

Restrictions on workers registering with trade unions

Role of trade unions as intermediaries

\section{Child labour:}

Prohibition on employment

Restrictions on employment by age or activity

Based on the analysis of contract clauses and the fieldwork, the following section discusses how such clauses can be put into operation. 


\section{Discussions and conclusion}

There is a high level of competition in the construction industry in the case study countries. In order to win bids contractors must keep their costs low and labour is often a major component of these costs. If, as is common, the client regularly awards contracts to the lowest bidder, the winning tender may be the one that pays the lowest wages, does not provide safety equipment or have coverage for accidents and has the largest proportion of casual workers. Such firms may actively discourage workers from joining unions. Meanwhile, in community contracting or self-help schemes using unpaid labour, there is frequently a lack of awareness of the necessity to apply national labour laws.

The underlying problem is not a lack of labour law. Rather, it is the lack of effective mechanisms to ensure those laws are applied and monitored. Ministries of labour and trade unions typically have insufficient resources to inspect sites or represent workers outside the major towns. In such situations the construction contract becomes an important mechanism for taking forward the implementation of labour standards and for demonstrating the benefits - for workers, contractors and employers. Contract clauses that relate specifically to labour standards can be included and/or strengthened.

Whilst such clauses place formal responsibility on the contractor, it is also important to develop a process to raise awareness for all stakeholders, and which puts in place agreed mechanisms for monitoring compliance.

\section{The process approach}

Developing the evidence base allowed the 'starting position' to be identified. In all 3 countries there appeared to be a process of 'slippage': national law was robust and covered most standards, National Framework Agreements reflected some standards, reference to labour standards in contract clauses was however minimal and rarely specific enough to provide sufficient guidance for implementation. In practice very few standards were being applied on site, although this varied between contractors and regions. In Ghana, greater attention was paid to certain labour standards (basic health and safety, payment on time, minimum wage) in gold mining areas, where construction work was in competition 
for labour. In areas of greater poverty, fewer experienced contractors and little financial and plant infrastructure, standards were granted less consideration.

Labour standards can only be successfully introduced and implemented through a process of consultation, involving all stakeholders. Together, these parties can agree mechanisms for implementing and monitoring compliance. Stakeholder consultation allowed issues raised through workshops and monitoring changes in site practice to be captured and recorded. Over time, a picture emerged of what needed to change for standards to be reflected in contracts (with the development of ideal forms of wording) and for those standards to then be applied on site.

\section{Recommendations for introducing labour standards}

Some of the key areas where improvements to the process of introducing labour standards are needed are summarised below:

\section{Contract documents}

- Labour standards should be considered in relation to the full range of contract documents from the Form of Agreement to general clauses in the Conditions of Contract.

- Additional clauses should be inserted into any special conditions or conditions of particular application, ensuring continuity with general conditions.

- Clauses usually express an intention to do something. Guidelines and checklists are therefore needed to identify how these clauses will be made operational.

\section{Costs}

- Implementing labour standards involves direct and indirect costs. These should be identified within the Preliminaries and accommodated within Prime Cost items in the Bill of Quantities (ensuring indirect costs for training, monitoring visits and so on are included). Any penalties for non-compliance of labour standards and rewards for full compliance (perhaps in the form 
of financial reimbursement, or social recognition) should also be clearly explained in the contract.

- The Employer will pay the increased costs of implementing labour standards in formal contracting, through higher bid prices. In due course, contractors familiar with the implications can improve their competitiveness in bidding.

- For community contracting and voluntary schemes, costs are included in the agreed price to be paid by government (or donors) for the work.

\section{Communication}

- Workers and communities need to be made aware of what their rights and entitlements are, and why they should receive them.

- Responsibility for raising awareness should be agreed and a communication strategy worked out with stakeholders, including the workers themselves.

\section{No monitoring, no compliance}

Without the application of incentives and/or sanctions, contractors are unlikely to see the need or benefit in implementing standards. Robust monitoring mechanisms are required that check on implementation. These can include:

- visual monitoring, to check on correct use of protective clothing and equipment and so on;

- viewing the record systems, to check on working hours, pay, accidents and so on; and

- discussions with workers.

Regular site meetings should act as a forum to discuss and address issues arising from the monitoring process. 


\section{Incentives or sanctions?}

- Incentives can be in the form of a drawdown payment to the contractor on completion, provided compliance with all labour standards has been achieved ${ }^{4}$.

- Sanctions may be in the form of disqualification from bidding for future contracts, withholding payment and/or social pressure applied at site meetings.

A combination of incentives and sanctions might prove most appropriate, with the criteria for compliance clearly identified and contractors fully informed of their implications prior to and during the bidding process.

It is important to be aware that in situations where a lack of capacity for effective site-based monitoring is a key issue, enforcing standards and therefore applying sanctions effectively will have its limitations.

\section{Impact}

- Monitoring the impact of labour standards on workers has two important aspects:

o ensuring a positive impact, with no unforeseen negative impacts; and

o increasing awareness among workers of their rights.

- Workers and communities should be involved in regular monitoring.

- Findings should be disaggregated to identify the impacts on female/male, permanent/casual, skilled/unskilled, migrant/local and poorest/less poor workers.

- Compliance and non-compliance should be recorded and tracked, including how situations of non-compliance have been dealt with.

- Grievances and mechanisms to address them also need to be recorded.

Experience gained from the case studies supports the following general conclusions:

- In situations of formal contracting (as in Ghana) effective implementation of labour standards can provide a win-win situation for both employers and employees.

\footnotetext{
${ }^{4}$ In informal contracting, social pressure may be the major incentive. Loss of social or political status can be a strong disincentive for non-compliance.
} 
- Community contracting (as in India) introduces complexities due to its informal nature and the extent to which social capital and the relationships between contractors and labourers impact on the work environment.

- The use of voluntary, unpaid labour (as in Zambia) should not be promoted. If used on a short-term basis, all stakeholders must be aware of the objectives of the approach and labourers of their rights. .

\section{Implementing the recommendations}

Implementing the recommendations to private or public works contracts cannot take place overnight and there is no given "blue-print”. A step-by-step approach should first identify the gaps where labour standards are missing from law and policy frameworks, standard contract documents and common site practice. Consultation with all relevant stakeholders can then identify a way ahead; agreeing roles and responsibilities, identifying which labour standards to focus on (if this is appropriate), planning a strategy for implementation and monitoring, and where possible eventually institutionalising labour standards into documents, defined responsibilities, future strategies and national agreements.

Whatever the context, implementing labour standards requires a collaborative effort between employers, supervisors, implementers, regulators and workers. This paper identifies practical and costeffective procedures for bringing stakeholders together to implement and monitor labour standards, with the aim of contributing to the overall goal of providing "decent work" for all workers in the construction industry. 


\section{Acknowledgements}

The authors would like to acknowledge the support of the Department for International Development (DFID), Sarah Ladbury (an independent consultant) and Mary Jennings (consultant) during the research programme. They are also most grateful for the assistance of the many people who have taken part from the case study countries. 


\section{References}

1. DFID (2004), Labour Standards and Poverty Reduction, Issues Paper, Department for International Development, London, UK.

2. Fédération Internationale des Ingénieurs-Conseils (1987), Conditions of Contract For Works of Civil Engineering Construction $4^{\text {th }}$ Edition, Parts 1 and 2 with Amendments (1996), Fédération Internationale des Ingénieurs-Conseils, Switzerland.

3. Health and Safety Commission, (undated), Comprehensive Statistics in support of the Revitalising Health and Safety programmes; Construction - national statistics, HSE website http://www.hse.gov.uk/statistics/pdf/rhscon.pdf (June 2005)

4. Helander M., (1991), "Safety hazards and motivation for safe work in construction industry", International Journal of Industrial Ergonomics, Vol. 8, No.3, pp. 205-223.

5. International Labour Organisation (ILO) (1987), Safety, Health and Welfare on Construction Sites: A Training Manual, International Labour Organisation, Geneva.

6. ILO (1998), Declaration on Fundamental Principles and Rights at Work, 86th Session, International Labour Organisation, Geneva.

7. ILO (1990), Training Manual on Safety, Health and Welfare on Construction Sites, ILO/UNDP Project RAS/86/072: Promotion of Safety, Health and Welfare in the Construction Industry, International Labour Organisation, Geneva.

8. ILO (1991), Regional Workshop on the Assessment of Relevant Policies and Programs in Construction (Phuket, Thailand, 15-17 April 1991), Proceedings and Country Papers, ILO/UNDP Project RAS/86/072: Promotion of Safety, Health and Welfare in the Construction Industry, International Labour Organisation, Geneva.

9. Ladbury, S. (2001), The Social Aspects of Construction Study (SAC), Briefing Paper prepared for the World Bank, unpublished.

10. Ladbury, S., Cotton, A. and Jennings, M. (2003), Implementing Labour Standards in Construction - A Sourcebook, WEDC, Loughborough University. 
11. Lubega, H., Kiggundu, B.M. and Tindiwensi, D. (2000), “An Investigation into the Causes of Accidents in the Construction Industry in Uganda”, proceedings of the 2nd International Conference on Construction in Developing Countries, 15-17th November 2000, Botswana.

12. United Nations (2002), “Implementing the Millennium Development Goals”, Fact Sheet, United Nations Department of Public Information, New York.

13. WHO/UNICEF JMP, (World Health Organization and United Nations Children's Fund Joint Monitoring Program) (2004), "Meeting the MDG Drinking Water and Sanitation Target: A Mid-Term Assessment of Progress”, Geneva and New York 